DOI: $10.4274 /$ tpa.45.225

\title{
Alerjik hastalıklarda immünoterapi
}

Immunotherapy in allergy

\author{
Nihat Sapan \\ Uludağ Üniversitesi Tıp Fakültesi, Çocuk Sağı̆ğı ve Hastalıkları Anabilim Dalı, Çocuk Alerji Bilim Dalı, Bursa, Türkiye
}

\begin{abstract}
Özet
Alerjen immünoterapi, alerjik etiolojiye dayanan hastalıkların tedavi yöntemlerinden biridir. Alerjen immünoterapide alerjik yakınmaları olan olgulara klinik bulguların kontrol altına alınması amacıyla, duyarlı olduğu alerjenin belirli aralıklarla ve giderek artan dozlarda verilmesiyle bu alerjene karşı tolerans gelişmesi amaçlanır. Özgül alerjen immünoterapi alerjik etiolojiye dayalı hastalıkların doğal seyrini değiştirmede etkili olabilen bir tedavi şeklidir. Alerjik hastalıkların tedavisinde en önemli yaklaşım alerjenden korunma ve birlikte kullanılacak olan ilaç tedavisidir. Çalışmalarda immünoterapi ile astım bulgularında anlamlı iyileşme sağlandığı, hastalarda ilaç kullanım gereğinin azaldığı, ayrıca alerjenlerle ve özgül olmayan uyarılar ile ortaya çıkan bronş aşırı duyarılığının azaldığı ortaya konmuştur. (Türk Ped Arş 2010; 45: 225-31)

Anahtar sözcükler: Alerji, alerjik hastalıklar, alerjen immünoterapi

\section{Summary}

Allergen immunotherapy is one of the methods in the treatment of allergic diseases. It is aimed in the allergen immunotherapy that tolerance is achieved by giving allergen extracts they are sensitized to the patients with allergic complaints in gradually increased doses in certain time intervals to abolish their clinical symptoms. Specific allergen immunotherapy can be an effective mode of treatment in changing the natural history of diseases with allergic etiology. The basic approach in the treatment of allergic diseases is to avoid allergens and medications simultaneously. It has been proven in a number of studies that significant improvements were achieved in asthma symptom scores, the need to use medications was decreased and bronchial hyperreactivity provoked by allergens or nonspecific stimulants was reduced with allergen specific immunotherapy. (Turk Arch Ped 2010; 45: 225-31)
\end{abstract}

Key words: Allergy, allergic diseases, allergen immunotherapy

\section{Giriş}

Alerjen immünoterapi (IT), alerjik etiolojiye dayanan hastalıkların tedavi yöntemlerinden biri olup, hastanın duyarlı olduğu alerjenin belirli aralıklarla ve giderek artan dozlarda kendisine verilerek bu alerjene karşı tolerans gelişmesini amaçlayan bilinen bir tedavi yöntemidir (1). İlk kez 1911 'de Noon ve Freeman $(2,3)$ tarafından alerjik rinitin tedavisinde kullanılmıştır. Alerjen immünoterapinin günümüzdeki başlıca gerekçeleri alerjik rinit, alerjik astım ve arı (venom) alerjisidir. Ayrıca lateks ve besin IT'si de son yıllarda üzerinde çalışmalar yapılan konular arasında yer almaktadır. Venom alerjisi IT'nin en etkin kullanım alanlarından biri olup, hastaların büyük çoğunluğunda 3-5 yıllık bir uygulamayı takiben kalıcı bir korunma sağlanmaktadır. Bu yazıda özellikle solunum yolu (inhalan) ve deri altından (subkutan) alerjen immunoterapi yöntemleri ele alınmıştır.

Alerjen immünoterapi alerjik etiolojiye dayalı hastalıkların doğal seyrini değiştirmede etkili olabilen bir tedavi şeklidir. Aslında alerjik hastalıkların tedavisinde en önemli yaklaşım alerjenden korunma ve birlikte kullanılacak olan ilaç tedavisidir. İyi bir çevresel kontrol uygulanabildiği takdirde hastaların yakınmaları kontrol altına alınabilir. Ancak alerjenlerden korunmanın mümkün olamadığı durumlarda IT tedavide bir seçenek olabilir. Özellikle polenler ve ev tozu akarları gibi yaygın alerjenlerden korunmak kolay değildir. Ayrıca alerjik

Yazışma Adresi/Address for Correspondence: Dr. Nihat Sapan, Uludağ Üniversitesi Tıp Fakültesi, Çocuk Sağlı̆ı ve Hastalıkları Anabilim Dalı, Çocuk Alerji Bilim Dalı, Bursa, Türkiye E-posta: nihatsapan@yahoo.com.tr

Gelis Tarihi/Received: 01.06.2010 Kabul Tarihi/Accepted: 22.06.2010 
hastalıkların tedavisi uzun süreli ilaç kullanımını gerektirebilir. Bu durumda ilaç kullanımında uyum sorunları yaşanabilmekte ya da ilaçlara bağlı bazı yan etkilerle karşılaşılabilmektedir. Bu gibi durumlarda yine IT bir tedavi seçeneği olarak düşünülebilir. Alerjen immünoterapisinin tedavide bir seçenek olabileceği durumlarda, hasta çocukların ebeveynlerinin konu hakkında geniş ölçüde bilgilendirilmeleri ve tedavi başlanmasında fikirlerinin alınması önemlidir.

\section{İmmunoterapinin klinik etkileri}

Burada özellikle inhalan alerjenlerle ilgili olarak alerjik rinit ve bronşiyal astım ele alınmıştır.

\section{Alerjik rinit}

Birçok çalışmada alerjik rinitli olgularda çeşitli polenlerle yapılan IT'nin etkinliği ortaya konmuştur. İnhalan alerjenlerle yapılan IT'nin en etkili olduğu grup özellikle polenlere duyarlılık saptanan alerjik rinitli olgulardır. Polenler ağaç polenleri, çayır polenleri ve yabani ot polenleri olarak üç bölümde incelenirler.

Alerjik rinitli olgularda immünoterapi tedavisinin değerlendirildiği 16 ileriye dönük, kör ve plasebo kontrollü çalışmanın incelendiği bir meta-analizde beş çalışmada alerjen olarak çayır polen ekstresi, altı çalışmada kanarya otu polen ekstresi, iki çalışmada D. pteronyssinus, iki çalışmada dağ sedir ağacı poleni ekstresi, bir çalışmada Alternaria küf sporu alerjen ekstresi kullanılmıştır (4). Bu çalışmaların 15'inde bulgulardaki iyileşme IT grubunda plaseboya göre daha iyi bulunmuştur (olasılık oranı 1,81).

Çoklu polen alerjilerinde IT tedavisinden yanıt alınması zorlaşır.

\section{Bronşiyal astım}

Bronşiyal astımlı olgularda çayır poleni, kedi alerjeni ve ev tozu akarları ile yapılan kontrollü çalışmalarda iT'nin etkili olduğu gösterilmiştir (5).

Rastgele, kontrollü toplam 3188 astımlı olgunun yer aldığı 75 çalışmanın incelendiği bir meta-analizde, 75 çalışmadan 36'sında ev tozu akarları, 20'sinde polen, 10'unda evcil hayvan alerjenleri, ikisinde Cladosporium, birinde lateks ile IT yapılmış olup, altı çalışmada ise çoklu alerjen ile IT uygulanmıştır (5). Çalışmalarda astım belirtilerinde anlamIı iyileşme sağlandığı, ayrıca ilaç kullanım gereğinin azaldığı ve ilaveten alerjenlerle ve özgül olmayan uyarı ile ortaya çıkan bronş aşırı duyarlıığının azaldığı ortaya konmuştur.

Ancak bazı çalışmalarda sınırlı yarar sağlanabildiği veya yarar sağlanmadığı da gösterilmiştir $(6,7)$. Bu nedenle astımlı olgularda yapılacak olan IT tedavilerinin önerileceği hastaların ve tedavide kullanılacak olan alerjen ekstrelerinin iyi seçilmesi gerekmektedir.

Aslında astımlı olgularda en sık rastlanan alerjenler ev tozu akarları olup, sadece ev tozu akarlarına duyarlılık saptanan olgularda öncelikle korunma önlemlerinin uygulanması ve yeterince yanıt alınamayan ve ilaç kullanımı azalmayan olgularda özgül İT düşünülmelidir.

\section{Özgül alerjenlerin klinik etkileri}

Alerjik hastalıklarda inhalan alerjen olarak karşılaşılan en önemli alerjenler polenler, ev tozu akarları, küf sporları ve evcil hayvan tüy ve deri döküntüleridir.

\section{Polenler}

Polenler genellikle alerjik rinit ve konjonktivit bulgularına neden olurlar. Çeşitli ülkelerde sıklıkla bulgulara neden olan polenler bölgelerin bitki örtüsüne göre değişirler. Örneğin Amerika Birleşik Devletleri'nde kanarya otu poleni, Ingiltere'de çayır polenleri daha sık bulgulara neden olurken, Akdeniz Bölgesi'nde yer alan ülkelerde zeytin ağacı poleni öne çıkmaktadır. Ülkemizde yine zeytin ağacı poleni ve ayrıca çayır polenlerinin en sık görülen alerjik polenler olduğu dikkati çekmektedir (8).

\section{Ev tozu akarları}

Özellikle astımlı olgularda en sık rastlanan alerjenlerdir. Deri testlerinde pozitif bulunması durumunda ev tozu akarları ile karşılaşılması halinde sıklıkla astım bulguları ortaya çıkmaktadır. Meta-analizlerde değerlendirilen astımlı olgularda yapılan iT çalışmalarının yaklaşık yarısında ev tozu akar ekstreleri kullanılmaktadır (5). Ayrıca yıl boyu görülen alerjik rinitli olgularda ev tozu akarları ile yapılan IT tedavileri de etkili bulunmuştur (9). Ev tozu akarlarından korunmada öncelikle ev içi nemin azaltılması, yatak ve yastık kılıflarının akar geçirmez kumaşlardan seçilmesi, ev içi ortamda toz tutucu perde, halı, mobilya aksamı gibi eşyalara dikkat edilmesi gerekmektedir.

\section{Hayvan tüy ve deri döküntüleri}

Ev tozu akarlarına benzer şekilde hayvan tüy ve deri döküntüleri de astımlı olgularda delme (prick) deri testlerinde sıklıkla pozitif bulunurlar ve astım bulgularına neden olurlar. Genellikle hayvan tüy ve deri döküntüleri korunulabilen alerjenler olarak kabul edilir. Ancak meslek ile ilgili olarak karşılaşıldığında bu durum sorun yaratabilir. Özellikle kedi alerjeninin genel ortamlarda yaygınlığı ve evde kedi bulunmamasına rağmen korunmada güçlükler içermesi nedeniyle IT tedavisinde kullanılması önerilebilir. İki çalışmada, kedi tüyü ile yapılan IT'de, evde kedi bulunmayan olgularda astım bulguları ile ilaç kullanma skorlarında iyileşme ve 'histamine-özgül olmayan bronşiyal aşırı duyarlılık' yanıtlarında azalma olduğu bildirilmiştir $(10,11)$.

\section{Küf sporları}

Küf sporları astım bulgularını ortaya çıkaran alerjenler olarak ağır astım ataklarına neden olabilirler. İki önemli dış ortam küf sporu olan Cladosporium ve Alternaria ile yapılmış çift kör plasebo kontrollü birkaç immünoterapi çalışması vardır (12-14). Bunlardan astımlı 30 çocuğun yer aldığı ve 10 aylık bir süre boyunca Cladosporium herbarium ile IT uygulanan bir çalışmada ilaç kullanımı anlamlı olarak azalmış ancak bulgularda anlamlı bir azalma olmamıştır (12). Erişkinlerde yapılan bir başka çalışmada 22 hastada 5-7 aylık bir sürede Cladosporium herbarium ile uygulanan IT ile bulgularında ve ilaç kullanımında plaseboya göre anlamlı azalma sağlanmıştır (13). 
Standardize Alternaria alerjen ekstratı ile bir yıllık bir süre boyunca IT uygulanan 24 alerjik rinit ve/veya astımlı olguda bulgu ve ilaç skorlarında anlamlı azalma ve Alternaria'ya deri ve burun duyarlıı̆ında azalma olduğu bildirilmiştir (14).

\section{Rehberlerde immünoterapi}

Genel olarak çeşitli hastalıkların tedavilerinde standardizasyonun sağlanması amacıyla rehberler yayınlanmaktadır. Alerjik hastalıklarla ilgili olarak çeşitli ülkelerde ve çeşitli kuruluşlar tarafından yayınlanan rehberlerin immünoterapi konusuna yaklaşımları aşağıdadır:

\section{GINA rehberi (2008) (15)}

\section{Alerjene-özgü immünoterapi}

Tedavideki rolü: Yetişkin astımında özgül iT rolü sınırlıdır. Uygun bir IT için klinik bulgulardan sorumlu olan tek alerjenin saptanması ve kullanılması önerilir. Ardından tolerans gelişmesi için alerjen gittikçe yükseltilerek yüksek dozlarda uygulanır.

Yetmiş beş rastgele plasebo kontrollü iT çalışmasının incelendiği bir Cochrane analizinde, î bulgularda ve ilaç kullanım skorlarını azaltmadaki etkileri ve alerjen özgül ve özgül olmayan havayolu aşırı duyarlıı̆ındaki etkileri ortaya konmuştur (5). Benzer etkiler dil altı IT için de bir sistematik incelemede ortaya konmuştur (16).

Özgül iT'nin klinik etkileri uzun süreli olup, alerjik rinokonjonktivitli olgularda tedavinin kesilmesinden sonraki yedi yıl süresince astım gelişmesinden de koruduğu ortaya konmuştur (17). Ancak tedavideki bu etki diğer tedavi yöntemleri ile karşılaştırıldığında, tedaviden sağlanacak yararlar, uzun enjeksiyon tedavi süresi, her enjeksiyonda 30 dakikalık bir bekleme süresi gibi zorluklar ve görülebilecek yan etkilerden daha iyi olmalıdır. Özgül iT sadece iyi bir çevresel önlem ve inhale kortikosteroidlerin kullanıldığı ilaç tedavisi programı uygulanmış ve astım kontrolünde başarısız kalınmış olan olgularda uygulanmalıdır (18). Özgül IT'nin astımda farmakolojik tedavi ile karşılaştırıldığı bir çalışma yoktur. Çoklu alerjenlerle IT yapılması önerilmez.

Yan etkiler: Özgül IT uygulanması sırasında lokal ve sistemik yan etkiler meydana gelebilir. Enjeksiyon yerindeki yan etkiler çok yavaş gelişen lokal sertlik ve kırmızılık şeklinde olabileceği gibi geniş ve ağrılı geç tepkiler de görülebilir. Sistemik reaksiyonlar olarak yaşamı tehdit edebilen anafilaktik reaksiyonlar ya da ağır astım atakları görülebilir. Ağır astımlı olgularda özgül IT ölümlere neden olabilir.

\section{İngiltere rehberi (2009) (19)}

\section{İmmünoterapi}

Yapılan üç kontrollü çalışmada, 8000 den fazla olguda, tekli alerjik bireylerde yapılan alerjen IT ile sonraki üç dört yıl içinde yeni alerjik duyarlılık gelişme olasılığının azaldığı dikkati çekmiştir (20-22).
Polen alerjenleri ile IT yapılmış olan alerjik rinitli çocuklarda üç yıllık tedavi süresi içinde astım görülme sıklığı düşük bulunmuştur (23). Bu etki tedavinin kesilmesinden sonraki iki yıllık süre içinde de benzer şekilde devam etmiştir (24).

Alerjen IT'nin birincil korumadaki yerini ortaya koyabilmek için çalışmalara intiyaç vardır.

\section{Amerikan rehberi (2007) (25)}

\section{İmmünoterapi}

İmmünoterapi, ilaçların etkisiz olması sebebiyle semptomların kontrol altına alınmasında zorluklar yaşanan, çokIu ilaç kullanımını gerektiren veya ilaç kullanımını kabul etmeyen hastalarda uygulanan bir tedavi yöntemidir.

Alerjen IT monosensitize çocuklarda ve erişkinlerde yeni alerjen duyarlılığı gelişmesini önler (20-22). Alerjik rinitli çocuklarda Birch ve Timothy (23) polen ekstreleriyle yapıIan IT astım gelişmesini önler. Alerjen IT'nin etkisi tedavinin kesilmesinden sonra en az üç yıl devam eder (26). Bu çaışmalar, hastanın bulgularının alerjik nedenlerden kaynaklandığına ait anlamlı bulgular varlığında IT'nin tedavide düșünülmesini destekler.

Özgül İT'nin alerjen özgül T regülatör hücrelerin ortaya çıkmasıyla T ve B hücre cevaplarının düzenlenmesi, alerjen özgül IgG4, IgG1 ve IgA'da artış, IgE'de azalma ve mast hücreleri ve bazofillerin dokuda yayılımında azalma gibi immünolojik cevapları başlattığı gösterilmiştir. Bu immünolojik değişikliklerin klinik bulgulara olan etkileri ortaya konmuştur (27).

Genellikle tek alerjen duyarlıı̆ı olan olgularda çayır poleni, kedi, ev tozu akarı, kanarya otu, Cladosporium, Alternaria ile yapılan kontrollü iT çalışmalarında astım bulgularının azaldığı gösterilmiştir $(6,13,14,28-30)$.

Yetmiş beş rastgele, plasebo kontrollü çalışmanın değerlendirildiği bir meta-analizde IT'nin astım bulgularını ve ilaç kullanımını azalttığı, bronşiyal aşırı duyarlııkta etkili olduğu gösterilmiştir (5). Bu meta- analizde ev tozu akarları ile yapılmış 36 çalışma, polenler ile yapılımış 20 çalışma ve hayvan alerjenleri ile yapılmış 10 çalışma bulunmaktadır. Ayrıca küf sporları ile yapılmış üç çalışma ve çoklu alerjenlerle yapılmış altı çalışma bulunmaktadır.

Amerika Birleşik Devletleri'nde ev tozu akarları, çayır, kanarya otu ve kedi için standardize ekstreler bulunmaktadır. Diğer polenler ve köpek alerjeni için ise standardize olmayan ekstreler bulunmaktadır ve bunların benzer şekilde etkili olduğu gösterilmiştir (31).

Hamamböceği ve küf ekstreleri ise çok değişken alerjen yapısına ve alerjenik özelliğe sahip olup özgül iT'deki etkinlikleri henüz gösterilememiştir (31).

Çoklu alerjenlerin kullanıldığı az sayıda çalışma vardır. Bunlardan birinde duyarlı bulunan çocuklara yüksek doz alerjen uygulandığında, aynı alerjenin daha düşük dozda 
uygulandığı ya da plasebo uygulanan gruba göre astım bulgularında azalma görüldüğü bildirilmiștir (32). Bir bașka çalıșmada en iyi medikal tedavi ile birlikte sadece yıl boyu süren alerjen olarak ev tozu akarları verilen olgularda aktif tedavi grubunda ve plasebo grubunda astım bulgularında iyileşme sağlanamamıştır (7).

Alerjen IT'nin devam süresi 3-5 yıldır. Özellikle iyi kontrol altına alınmamış olan astımlı olgularda, alerjik rinitli olgularla karşılaştıııldığında, IT sırasında şiddetli bronkospazm gibi ağır ve bazen ölümcül olabilen tepkiler görülebilir $(33,34)$. Alerjen IT uygulaması sadece hayatı tehdit edici herhangi bir durumun tedavi edilebileceği olanaklara ve çaIışana sahip doktor muayenehanelerinde yapılmalıdır (35). Bu nedenle astımda IT uygulaması için uzmanlar farklı görüşler ileri sürmektedirler $(7,36,37)$.

Avrupa'da dil altı IT uygulaması giderek artmaktadır (38). Astımda etkili olduğu ve tedavinin kesilmesinden sonraki 4-5 yıllık süre boyunca bu etkinin devam ettiği gösterilmiştir. Ayrıca sistemik deri altı tepkimesi yoktur ve bu nedenle evde uygulanabilmektedir (39). Karşılaştırmalı çalışmalarda deri altı enjeksiyonun iT'ye göre daha az etkili olduğu bildirilmiştir $(40,41)$.

\section{Practall çalışma grubu (2008) (42)}

\section{İmmünoterapi}

Alerjen IT uzun bir dönem boyunca artan dozlarda alerjenin verilmesiyle tedavi edici bir doza ulaşılmasını takiben alerjenin doğal yollarla karşılaşılması durumunda ortaya çıkan alerjik yakınmalara karşı korunma sağlanması durumunu ifade etmektedir. Bu tür immün düzenlenme alerjik astımın tedavisinde kalıcı iyileşme sağlanmasının tek yoludur (43).

Koruyucu etki: Özgül iT diğer alerjenlere karşı duyarlılaşmayı önleyebilir $(7,22)$. Astımlı olgularda iyileşme sağlayabilir ve aynı zamanda alerjik rinitli olguların astıma dönüşmesini engelleyebilir ve mevsimsel alerjileri olan olgularda astım gelişimini azaltır (22,43-45). Alerjen IT'nin etkisi tedavinin kesilmesinden sonra da devam eder. Alerjik rinit bulgularında uzun bir klinik iyileşme dönemi görülür (47).

Etki: Yetmiş beş çalışmanın yer aldığı bir meta-analize dayanarak alerjenlerin etkisinin kanıtlandığı astımlı olgularda IT önerilebilir (5). Alerjen IT'nin etkisi kullanılan alerjen ekstrelerinin niteliğine bağlıdır.

Deri altı enjeksiyon iT: Iyi planlanmış çalışmalarda enjeksiyon IT'nin astımlı olgularda ilaç kullanımını azalttığı, bronşiyal aşırı duyarlılık ve bronkospazm gibi astım bulgularında kalııı iyileşme sağladığı gösterilmiştir (5).

Çocukluk çağında yapılan mevsim öncesi çayır polen iT ile altı yıllık dönemde ve 12 yıllık dönemde anlamlı klinik yarar sağlandığı bildirilmiştir $(48,49)$.

Ayrıca 16 yaş ve sonrasındaki çocuklarda deri altı iT maliyet yarar analizinde yararlı bulunmuştur (50).
Dil altı iT: Dil altı IT (SLIT) çocuklarda deri altı IT'ye karşı güvenli ve etkili bir seçenek olabilir (51). Ancak beş yaşın altındaki çocuklarda etkisi konusunda yeterince veri yoktur (51). Bir sistematik incelemede sadece ev tozu akarlarına alerjisi olan dört yaşın üzerindeki hafif-orta astımlı çocuklarda SLiT'in klinik bulgulara düşük-orta derecede etkili olduğu sonucuna varılmışıı (52). ARIA Çalışma Grubu tarafından mevsimsel alerjik rinitte daha önceki dönemde önerilmesine rağmen bu gerekçede etkisi yetersiz bulunmuştur (53). Ancak yeni bir meta analizde plasebo ile karşılaştırıldığında standardize ekstrelerle yapılan SLiT çocuk olgulardaki alerjik rinitte etkili bulunmuştur (54).

Bugüne kadar bildirilen ağır astım ve SLiT nedeniyle ortaya çıkan anafilaksi olgularında SLiT in güvenilirliği yeterince ortaya konamamıştır (55). Yeni bilgiler SLiT in alerjik rinit ve konjonktivitte ve çayır polenle indüklenmiş 18 yaş ve üzerindeki astımlı olgularda daha etkili olduğuna dikkat çekmektedir (56). Yüksek dozların etkili olabileceğine ait bazı bulgular mevcut olmasına rağmen henüz yetki alamamış olup, bu konuda daha fazla çalışmalara intiyaç vardır.

Enjeksiyon iT ya da SLiT: Deri altı IT'yi takiben ağır ve ölümcül anafilaksi bildirilmiştir $(5,33)$. Tamamen güvenli olmamasına rağmen etkili bir SLiT çocuklar, anne babalar ve doktorlar için enjeksiyon iT'ye bir seçenek olabilir. Çocuklarda yapılan ve enjeksiyon IT ile SLiT in karşılaştııılığı bazı çalışmalarda benzer etkiler bildirilmiştir; fakat SLiT'in tam olarak etkili olduğu konusunda halen eksikler vardır $(40,57)$.

Olgu seçimi: Alerjik hastalıkların tedavisi alerjenden korunma, ilaç tedavisi, alerjen IT ve olgunun eğitimi şeklinde olmalıdır. Alerjen immünoterapinin diğer tedavi yöntemleri ile birlikte yapılması alerjinin fizyopatolojik mekanizması göz önünde tutulduğunda hastanın olabildiğince bulgusuz bir hale getirilmesi konusunda geniş bir tedavi yaklaşımı sunar (53). Alerjen immünoterapinin erken başlanması sadece tedavi yaklaşımı açısından değil aynı zamanda koruma açıdan da bronşiyal enflamasyonu azaltması nedeniyle özellikle çocuklarda önerilir. Alerjik duyarlılık olmayan astımlı olgularda IT uygulaması yoktur.

Önlemler: Enjeksiyon IT sadece eğitilmiş çalışan tarafından ve uzmanlığı olan bir doktor denetiminde uygulanmalıdır. Alerjen IT genellikle güvenli bir tedavi yöntemi olmasına rağmen bazı önlemler alınmalıdır :

1. Uygulama acil tedavi yapılabilecek adrenalin, oksijen, kortikosteroid ve temel yaşam desteği verilebilecek bir setin bulunduğu ortamda yapılmalıdır.

2. Hastalar enjeksiyonu takiben en az 30 dakika klinikte tutulmalıdır.

3. Klinikte yan etki görülen olgulara acil tedavi (IM adrenalin ve oksijen gibi) uygulanır ve stabilize edilmelerini takiben hastaneye gönderilirler.

4. Hastalara olumlu etkileri ile birlikte muhtemel yan etkileri konusunda yeterince bilgi verilmelidir. 


\section{Öneriler}

1. Alerjik astım için kabul edilmiş gerekçeler dahilinde alerjik durumu iyice belirlenmiş olan olgularda uygun alerjen ekstrelerinin kullanılması ile IT başlanablilir.

2. Alerjen IT uygun çevresel kontrol ve ilaç tedavisine ek olarak başlanmalıdır.

3. Stabil olmayan astımda IT önerilmez. Tedavi yapılacağı sırada hastanın yakınması varsa solunum testinde FEV1 değeri \%80'den yüksek olmalıdır, aksi takdirde IT uygulanmamalıdır.

4. Birden fazla alerjene duyarlı olma durumu IT için bir kontrendikasyon oluşturmaz, fakat çoklu alerjenlerin aynı anda verilmesiyle tek bir antijen için gerekli olan doza ulaşmakta sorun olacağından tedavinin etkisini azaltabilir.

5. Yaş tam olarak bir kontrendikasyon değildir, üç yaşından itibaren ancak iyi donanımlı merkezlerde çok iyi bir kontrolün sağlanması durumunda önerilebilir.

6. Olgular düzenli tedaviye uyum göstermelidir.

\section{Türk Toraks Derneği rehberi (2009) (58)}

\section{Alerjen immünoterapisi}

Günümüzde alerjik astım tedavisinin temelini çevresel korunma ve ilaç tedavisi oluşturur. Alerjen iT'sinin erişkin astımında rolü sınırlıdır. Öncelikle alerjik duyarlanma deri testi ve/veya in vitro test ile gösterilmeli ve öyküde de alerjenle temasın astım bulgularına yol açtığı doğrulanmalıdır $(15,59)$. Uygulamada tek ve standardize bir alerjene duyarlı hastada, klinik açıdan önemli alerjenin standart ekstresi tolerans oluşturmak amacıyla giderek artan dozlarda verilir.

İmmünoterapi uygulama koşulları

- Hastaya anafilaksi riski açıklanmalı ve yazılı onayı alınmalı, anafilaksi önlemlerinin alındığı merkezlerde ve alerji uzmanı tarafından uygulanmalıdır.

- Standart sıvilar kullanılmalıdır.

- 12 ay sonra olumlu etki saptanmazsa IT kesilmelidir

- Gebelikte IT başlanmamalı, başlanmışsa doz artıımına gidilmemelidir.

- Tedaviye rağmen FEV1 değeri \%70'den düşük olan astımlılarda IT düşünülmemelidir.

- Ayrıca otoimmün hastalıklar, hipertansiyon, psikolojik sorunu olan ve uyumsuz hastalarda iT kontrendikedir $(15,59)$.

Yan etkileri: Alerjen IT uygulanırken lokal ve sistemik yan etkiler ortaya çıkabilir. Lokal olarak enjeksiyon bölgesinde kabarıklık, kızarıklık, geniş ve ağrılı tepkiler ortaya çıkabilir.

Sistemik tepkiler de yaşamı tehdit edebilen anafilaktik tepki ve şiddetli astım alevlenmeleridir. Ağır astımlı hastalar arasında iT' ye bağlı ölümler bildirilmiştir (15).

\section{Çocuk Solunum Yolu Hastalıkları Derneği, Çocukluk çağı astımında tanı ve tedavi önerileri (1999) (60)}

\section{İmmünoterapi}

Genelde beş yaşın üzerindeki hastalara uygulanmalıdır. Beş yaş altında ise nadiren kullanılabilir. İmmünoterapi, saptanan alerjenlerle çocuğun astımı arasında belirgin bir ilişki varsa yapılmalıdır. Mevsimsel rinokonjonktivit + astım hastalarında yararlıdır. Çocuklarda erişkinlere göre daha etkilidir. Meta-analiz çalışmaları astımda klinik düzelme sağlayabileceğini göstermektedir. Ancak IT, uygun çevresel kontrolün sağlanmasının veya ilaç tedavisinin yerini alamaz. Alerjen iT kararı alerji uzmanları tarafından verilmelidir.

\section{Komplikasyonlar ve genel değerlendirme}

Rehberlerdeki durumu ortaya koyduktan sonra şimdi de deri altı IT sonrası görülen komplikasyonlara göz atalım.

Alerjen IT'yi takiben lokal yada sistemik komplikasyonlar görülebilmektedir.

Lokal komplikasyonda enjeksiyon bölgesinde şişlik ya da kızarıklık ve kaşıntı olabilir. Hafif ya da geniş lokal tepkiler görülebilir. Geniş lokal tepkilerde buz tatbik edilmesi ve IT dozunun düşürülmesi önerilir.

Sistemik komplikasyon olarak anafilaksi meydana gelebilir ki bu durumda hasta yakın izleme alınır ve iT enjeksiyonlarının devam kararı gözden geçirilir.

Yaptığımız bir çalışmada lokal ve sistemik tepkilerin oranı değerlendirildiğinde lokal tepki, tüm enjeksiyonların $\% 5,8$ 'inde görüldü (61). Geniş lokal tepki ise tüm enjeksiyonların \%0,6 sında saptandı. Tüm enjeksiyonların ise \%0,4 ünde sistemik tepki saptandı (61). Sistemik tepkilerin önemli bir kısmı alerjenlerin doz artıımları safhalarında ortaya çıkmıştır. Sistemik tepkiler gelişen iki hasta tepkileri ciddi olarak değerlendirildiği için IT programından çıkarılmak zorunda kalınmıştır. Diğer hastalarda gerekli doz ayarlamaları yapılarak, enjeksiyon öncesi ve sonrasında hastalar dikkatle değerlendirilmiş, alerjen dozları düzenlenerek tedaviye ciddi sistemik tepkiler gözlenmeden devam edilmiştir.

Bütün olguların alerjen IT enjeksiyonu sonrasında en az 30 dakika gözlenmesi önerilmektedir. Ayrıca bulgusu bulunan hastalara IT uygulanmamalıdır.

Alerjen immünoterapi sırasında görülen yan etkilerin azaltılması ile ilgili çalışmalar devam etmektedir. Uygulanan alerjenin yapısı ile ilgili olarak bazı çalışmalar yapılmaktadır. Alerjenin etkili olma durumu değiştirilmeden yan etki durumunun azaltılması ve daha güvenli iT uygulamasının yapılabilmesi hedef alınmaktadır. Bu çalışmalar iki önemli grup içermekte olup birinde spesifik IgE'ye bağlanma yeteneği azaltılmış, ancak immünojenik aktivitesi korunmuş rekombine alerjenlerin kullanılmasıyla, diğerinde ise alerjenlerin tümü yerine alerjik yanıtta etkili olan ve laboratuvar ortamında sentezlenmiş peptit parçacıkları ile yapılan peptit iT ile $T$ hücre yanııının etkilenebildiği gösterilmiştir (62). 
Ayrıca deri altı IT yerine dil altı kullanılmasının daha güvenli bir IT sağladığından söz etmiştik. Günümüzde tablet IT kullanımı ile ilgili çalışmalarda başarılı sonuçlar elde edildiği bildirilmektedir. Ancak şimdilik kısıtlı bazı alerjenler ile yapılabilmekte olup, daha çok alerjenle yapılabilecek şekilde yaygınlaşması tedavide iyi bir seçenek oluşmasını sağlayabilecektir (63).

\section{Sonuçlar}

1. Özgül alerjen IT, alerjik etiolojiye dayanan hastalıkların tedavi yöntemlerinden biri olup, hastanın duyarlı olduğu alerjenin belirli aralıklarla ve giderek artan dozlarda kendisine verilerek bu alerjene karşı tolerans gelişmesini amaçlayan standart bir tedavi yöntemidir.

2. Alerjen IT alerjik etiolojiye dayalı hastalıkların doğal seyrini değiştirmede etkili olabilen bir tedavi șeklidir.

3. Alerjik hastalıkların tedavisinde en önemli yaklaşım alerjenden korunma ve birlikte kullanılacak olan ilaç tedavisidir.

4. Çalışmalarda IT ile astım bulgularında anlamlı iyileşme sağlandığı, ilaç kullanım gereğinin azaldığı, ayrıca alerjenlerle ve özgül olmayan uyarı ile ortaya çıkan bronş aşırı duyarlılığının azaldığı ortaya konmuştur.

5. Uygun bir IT için klinik bulgulardan sorumlu olan tek alerjenin saptanması ve kullanılması önerilir.

6. Tekli alerjik bireylerde yapılan alerjen IT ile sonraki üç dört yıl içinde yeni alerjik duyarlılık gelişme olasılığı azalmaktadır.

7. Polen alerjenleri ile IT tedavisi yapılmış olan alerjik rinitli çocuklarda üç yıllık tedavi süresi içinde astım görülme sıklığı düşük bulunmuştur.

8. Alerjen IT'nin başlanma yaşı beş yaş olup, devam süresi 3-5 yıldır.

9. Alerjen immünoterapi başlanmasına çocuklar için çocuk alerji uzmanları tarafından, erişkinler için ise erişkin alerji uzmanları tarafından karar verilmeli ve izlenmelidir.

10. Hastalar enjeksiyonu takiben en az 30 dakika kadar gözlenmelidir.

11. Standart allerjen solüsyonları ile IT yapılmalıdır.

12. Bir yıl sonra olumlu etki saptanmazsa IT sonlandırılmalıdır.

\section{Kaynaklar}

1. Nelson HS. Immunotherapy for inhalant allergens. In: Adkinson Jr NF, Bochner BS, Busse WW, Holgate ST, Lemanske Jr RF, Simons FER (eds). Middleton's Allergy Principles and Practice. Seventh edition. Philadelphia: Mosby Elsevier, 2009: 1657-77.

2. Noon L. Prophylactic inoculation against hay fever. Lancet 1911; 1: 1572-3.

3. Freeman J. Further observations on the treatment of hay fever by hypodermic inoculations of pollen vaccine. Lancet 1911;2: 814-7.

4. Ross RN, Nelson HS, Finegold I. Effectiveness of specific immunotherapy in the treatment of allergic rhinitis: an analysis of randomized, prospective, single- or double-blind, placebo-controlled studies. Clin Ther 2000; 22: 342-50.

5. Abramson MJ, Puy RM, Weiner JM. Allergen immunotherapy for asthma. Cochrane Database Syst Rev 2003: CD001186. Abstract / Full Text)

6. Creticos PS, Reed CE, Norman PS, et al. Ragweed immunotherapv in adult asthma. N Engl J Med 1996; 334: 501-6. Abstract apy in adult ast
7. Adkinson Jr NF, Eggleston PA, Eney D, et al. A controlled trial of immunotherapy for asthma in allergic children. N Engl J Med 1997; 336: 324-31. Abstract / Eull Tex / PDH

8. Bıçakçı A, Altunoğlu MK, Bilișik A, ve ark. Türkiye'nin atmosferik polenleri. Asthma Allergy Immunol 2009; 7: 11-7. PDH

9. Varney VA, Tabbah K, Mavroleon G, Frew AJ. Usefulness of specific immunotherapy in patients with severe perennial allergic rhinitis induced by house dust mite: a double-blind, randomized, placebo-controlled trial. Clin Exp Allergy 2003; 33: 1076-82. Abstract/ Full Tex / PDA

10. Alvarez-Cuesta E, Cuesta-Herranz J, Puyana-Ruiz J, CuestaHerranz C, Blanco-Quirós A. Monoclonal antibody-standardized cat extract immunotherapy: risk:benefit effects from a double-blind placebo study. J Allergy Clin Immunol 1994; 93: 556-66. Abstract / Full Tex / PDH

11. Hedlin G, Graff-Lonnevig V, Heilbron H, et al. Immunotherapy with cat- and dog-dander extracts. V. Effects of 3 years of treatment. J Allergy Clin Immunol 1991; 87: 955-64. Abstrac / Full Text

12. Dreborg S, Agrell B, Foucard T, Kjellman NI, Koivikko A, Nilsson S. A double-blind, multicenter immunotherapy trial in children using a purified and standardized Cladosporium herbarum preparation. Allergy 1986; 41: 131-40. Abstract

13. Malling HJ, Dreborg S, Weeke B. Diagnosis and immunotherapy of mould allergy. V. Clinical efficacy and side effects of immunotherapy with Cladosporium herbarum. Allergy 1986; 41: 507-19. Abstract

14. Horst M, Hejjaoui A, Horst V, Michel FB, Bousquet J. Doubleblind, placebo-controlled rush immunotherapy with a standardized Alternaria extract. J Allergy Clin Immunol 1990; 85: 460-72. Abstract

15. Global initiative for asthma. Global strategy for asthma management and prevention. Updated 2008: 34

16. Calamita Z, Saconato H, Pela AB, Atallah AN. Efficacy of sublingual immunotherapy in asthma: systematic review of randomized-clinical trials using the Cochrane Collaboration method. Allergy 2006; 61: 1162-72.

17. Jacobsen L, Niggemann B, Dreborg S, et al. (The PAT investigator group). Specific immunotherapy has long-term preventive effect of seasonal and perennial asthma: 10-year follow-up on the PAT study. Allergy 2007; 62: 943-8. Abstract / Eull Tex / PDH

18. Bousquet J, Lockey R, Malling HJ, et al. Allergen immunotherapy: therapeutic vaccines for allergic diseases. World Health Organization. American Academy of Allergy, Asthma and Immunology. Ann Allergy Asthma Immunol 1998; 81: 401-5. Abstract

19. British Guideline on the Management of Asthma. A national clinical guideline. May 2008 revised June 2009: 27.

20. Purello-D'Ambrosio F, Gangemi S, Merendini RA, et al. Prevention of new sensitizations in monosensitized subjects submitted to spesific immunotherapy or not. A retrospective study. Clin Exp Allergy 2001; 31: 1295-302. Abstract / Eull Text / (PDF)

21. Pajno GB, Barberio G, de Luca F, Morabito L, Parmiani S. Prevention of new sensitizations in asthmatic children monosensitized to house dust mite by spesific immunotherapy. A six-year follow-up study. Clin Exp Allergy 2001; 31: 1392-7. Abstract / Eull Tex / PDA

22. Des Roches A, Paradis L, Menardo JL, Bouges S, Daures JP, Bousquet J. Immunotherapy with standardized dermathophagoides pteronyssinus extract. VI. Specific immunotherapy prevents the onset of new sensitizations in children. J Allergy Clin Immunol 1997; 99: 450-3. Abstract / Full Tex / PDA

23. Moller C, Dreboprg S, Ferdousi HA, et al. Pollen immunotherapy reduces the development of asthma in children with seasonal rhinoconjunctivitis (the PAT-study). J Allergy Clin Immunol 2002; 109: 251-6. Abstract / DDA 
24. Niggemann B, Staden U, Rolinck-Werninghaus C, Beyer K Specific oral tolerance induction in food allergy. Allergy 2006; 61: 808-11. Abstract/ Full Tex/ PDH

25. National Heart, Lung, and Blood Institute. National Asthma Education and Prevention Program. Expert panel report 3 guidelines for the diagnosis and management of asthma (full report 2007): 172

26. Durham SR, Walker SM, Varga EM, et al. Long-term clinical efficacy of grass-pollen immunotherapy. N Engl J Med 1999; $341: 468-75$. Abstract / [Full Tex / PDH

27. Akdis $M$, Akdis CA. Mechanisms of allergen-specific immunotherapy. J Allergv Clin Immunol 2007; 119: 780-9. Epub February 2007. Abstract / Eull Tex / PDA

28. Olsen OT, Larsen KR, Jacobsan L, Svendsen UG. A 1-year, placebo-controlled, double-blind house-dust-mite immunotherapy study in asthmatic adults. Allergy 1997; 52: 853-9. Abstract

29. Reid MJ, Moss RB, Hsu YP, Kwasnicki JM, Commerford TM, Nelson BL. Seasonal asthma in northern California: allergic causes and efficacy of immunotherapy. J Allergy Clin Immunol 1986;7 8: 590-600. Abstract

30. Varney VA, Edwards J, Tabbah K, Brewster H, Mavroleon G, Frew AJ. Clinical efficacy of specific immunotherapy to cat dander: a double-blind placebo-controlled trial. Clin Exp Allergy 1997; 27: 860-7. Abstract

31. Nelson HS. Allergen immunotherapy: Where is it now? J Allergy Clin Immunol 2007; 119: 769-77. Epub March 2007. Abstract Eull Tex / PDA

32. Johnstone DE, Dutton A. The value of hyposensitization therapy for bronchial asthma in children -- a 14-year study. Pediatrics 1968; 42: 793-802. Abstract

33. Bernstein DI, Wanner M, Borish L, Liss GM. Immunotherapy Committee, American Academy of Allergy, Asthma and Immunology. Twelve-year survey of fatal reactions to allergen injections and skin testing: 1990-2001. J Allergy Clin Immunol 2004; 113: 1129-36. [Abstract) / Full Text) / PDA

34. Reid MJ, Lockey RF, Turkeltaub PC, Platts-Mills TA. Survey of fatalities from skin testing and immunotherapy 1985-1989. J Allergy Clin Immunol 1993; 92: 6-15. Abstract

35. American Academy of Allergy and Immunology Board of Directors. Guidelines to minimize the risk from systemic reactions caused by immunotherapy with allergenic extracts. J Allergy Clin Immunol 1994; 93: 811-2. Abstract

36. Canadian Society of Allergy and Clinical Immunology. Guidelines for the use of allergen immunotherapy. CMAJ 1995; 152: 1413-9.

37. Frew AJ. Injection immunotherapy. British Society for Allergy and Clinical Immunology Working Party. BMJ 1993; 307: 919-23. Abstract

38. Canonica GW, Passalacqua G. Noninjection routes for immunotherapy. J Allergy Clin Immunol 2003; 111: 437-48. Abstract / Full Tex] / PDH

39. Di Rienzo V, Marcucci F, Puccinelli P, et al. Long-lasting effect of sublingual immunotherapy in children with asthma due to house dust mite: a 10-year prospective study. Clin Exp Allergy 2003; 33: 206-10. Abstract / Full Tex / PDH

40. Khinchi MS, Poulsen LK, Carat F, Andre $C$, Hansen AB, Malling HJ. Clinical efficacy of sublingual and subcutaneous birch pollen allergen-specific immunotherapy: a randomized, placebo-controlled, double-blind, double-dummy study. Allergy 2004; 59: 45-53. Abstract / Full Tex / PDA

41. Lima MT, Wilson D, Pitkin L, et al. Grass pollen sublingual immunotherapy for seasonal rhinoconjunctivitis: a randomized controlled trial. Clin Exp Allergy 2002; 32: 507-14. Abstrac / Eull Tex / PDA

42. Bacharier $\mathrm{LB}$, Boner $\mathrm{A}$, Carlsen $\mathrm{KH}$, et al. Diagnosis and treatment of asthma in childhood : a PRACTALL consensus report. Allergy 2008; 63: 5-34. Abstract / Full Tex/ PDA

43. Pajno GB. Allergen immunotherapy in early childhood: between Scylla and Charybdis. Clin Exp Allergy 2005; 35: 551-3. Abstract / Full Tex / PDH

44. Grembiale RD, Camporota L, Naty S, Tranfa CM, Djukanovic R, Marsico SA. Effects of specific immunotherapy in allergic rhinitic individuals with bronchial hyperresponsiveness. Am J Respir Crit Care Med 2000; 162: 2048-52. Abstract
45. Niggemann B, Jacobsen L, Dreborg S, et al. Five-year followup on the PAT study: specific immunotherapy and long-term prevention of asthma in children. Allergy 2006; 61: 855-9.

46. Novembre E, Galli E, Landi F, et al. Coseasonal sublingual immunotherapy reduces the development of asthma in children with allergic rhinoconjunctivitis. J Allergy Clin Immunol 2004; 114: 851-7. Abstrac / Eull Tex / PDH

47. Durham SR, Walker SM, Varga EM, et al. Long-term clinical efficacy of grass-pollen immunotherapy. N Engl J Med 1999; 341: 468-75. Abstract / Full Tex / PDH

48. Eng PA, Reinhold M, Gnehm HP. Long-term efficacy of preseasonal grass pollen immunotherapy in children. Allergy 2002; 57: 306-12. Abstract / PDA

49. Eng PA, Borer-Reinhold M, Heijnen IA, Gnehm HP. Twelveyear follow-up after discontinuation of preseasonal grass pollen immunotherapy in childhood. Allergy 2006; 61: 198-201. Abstract / Full Tex / PDB

50. Petersen KD, Gyrd-Hansen D, Dahl R. Health-economic analyses of subcutaneous specific immunotherapy for grass pollen and mite allergy. Allergol Immunopathol 2005; 33: 296-302. Eull Tex

51. Olaguibel JM, varez Puebla MJ. Efficacy of sublingual allergen vaccination for respiratory allergy in children. Conclusions from one meta-analysis. J Investig Allergol Clin Immunol 2005; 15: 9-16. PDH

52. Sopo SM, Macchiaiolo M, Zorzi G,Tripodi S. Sublingual immunotherapy in asthma and rhinoconjunctivitis; systematic review of paediatric literature. Arch Dis Child 2004; 89: 620-4. Abstract / PDF

53. Bousquet J, Van CP, Khaltaev N. Allergic rhinitis and its impact on asthma. J Allergy Clin Immunol 2001; 108: 147-334.

54. Penagos M, Compalati E, Tarantini F, et al. Efficacy of sublingual immunotherapy in the treatment of allergic rhinitis in pediatric patients 3 to 18 years of age: a metaanalysis of randomized, placebo-controlled,double-blind trials. Ann Allergy Asthma Immunol 2006; 97: 141-8. Abstract

55. Eifan AO, Keles S, Bahceciler NN, Barlan IB. Anaphylaxis to multiple pollen allergen sublingual immunotherapy. Allergy 2007; 62: 567-8. Abstract / Full Tex / PDA

56. Durham SR, Yang WH, Pedersen MR, Johansen N, Rak S. Sublingual immunotherapy with once-daily grass allergen tablets: a randomized controlled trial in seasonal allergic rhinoconjunctivitis. J Allergy Clin Immunol 2006; 117: 802-9. Abstract] / Eull Text/[PDH

57. Mungan D, Misirligil Z, Gurbuz L. Comparison of the efficacy of subcutaneous and sublingual immunotherapy in mite-sensitive patients with rhinitis and asthma- a placebo controlled study. Ann Allergy Asthma Immunol 1999; 82: 485-90. (Abstract

58. Türk Toraks Derneği Astım Tanı ve Tedavi Rehberi. Türk Toraks Dergisi 2009; 10: 25-6.

59. Toraks Derneği, Ulusal Astım Tanı ve Tedavi Rehberi.Toraks Dergisi 2000: 1; 4-31.

60. Çocukluk Çağı Astımında Tanı ve Tedavi Önerileri. Çocuk Solunum Yolu Hastalıkları Derneği 1999: 7.

61. Canıtez Y, Öztürk RC, Sapan N. Alerjen spesifik immünoterapide lokal ve sistemik reaksiyonlar. Güncel Pediatri 2007; 5: 92-5. (Abstract) / Full Tex / PDA

62. Larche M. Update on the current status of peptide immunotherapy derived from a variety of allergens. J Allergy Clin Immunol 2007; 119: 906-9. Abstract

63. Durham SR, Emminger W, Kapp A, et al. Long-term clinical efficacy in grass pollen-induced rhinoconjunctivitis after treatment with SQ-standardized grass allergy immunotherapy tablet. J Allergy Clin Immunol 2010; 125: 131-8. [Abstract / Eull Tex / 